\title{
LEAD POISONING IN GULF OF YOUTEFA, JAYAPURA, PAPUA
}

\author{
Hasmi \\ Faculty of Public Health, Cendrawasih University, Jayapura
}

\begin{abstract}
Background: Lead is a cumulative toxicant that affects multiple body systems and is particularly harmful to young children. Its widespread use has resulted in extensive environmental contamination, human exposure and significant public health problems in many parts of the world. Young children are particularly vulnerable to the toxic effects of lead and can suffer profound and permanent adverse health effects, particularly affecting the development of the brain and nervous system. This study aimed to investigate lead poisoning in Gulf of Youtefa, Jayapura, Papua, particullary it aimed to estimate lead level in water, fish, and shell in the Gulf of Youtefa.

Subjects and Method: This was a descriptive cross sectional study conducted in Gulf of Youtefa, Jayapura, Papua. A sample of 75 community members living adjacent to Gulf of Youtefa were selected for this study. In addition, samples of water, fish, and shell were taken from 12 stations in the Gulf of Youtefa. The dependent variable was lead level. Lead poisoning in human subjects was measured from urine sample by Liquid Chromatography Mass Spectrophotometry Detector. Samples of water, fish, and shell were measured by Inductively coupled plasma Thermo IRIS Interepid II.
\end{abstract}

Results: All study subjects showed corpoporphyrin level $\geq 20 \mu \mathrm{g} / \mathrm{dL}$ indicating lead poisoned, consisting of 57 (76\%) females and 18 (24\%) males. Out of 57 females, 18 (31.5\%) were at reproductive age (20-35 years old), 29 $(68.5 \%)$ females were $\geq 35$ years old. Mean lead level in water was 0.0265 indicating lead polluted since it exceeded $\geq 0.008 \mathrm{mg} / \mathrm{L}$. Lead level in fish was $2.16 \mathrm{mg} / \mathrm{kg}$ indicating lead polluted since it exceeded $\geq 0.3 \mathrm{mg} / \mathrm{kg}$. Lead level in the shell was $0.57 \mathrm{mg} / \mathrm{kg}$ indicating lead polluted since it exceeded $\geq 0.3$ $\mathrm{mg} / \mathrm{kg}$.

Conclusion: All study subjects are lead poisoned. Twelve water stations are lead polluted. Fish and shell are also lead polluted.

Correspondence: Hasmi. Faculty of Public Health, Cendrawasih University, Jayapura. Email: hasmiuncen@yahoo.co.id.

Mobile: +6285244617411. 